Article

\title{
Designing and Validating a Model for Measuring Sustainability of Overall Innovation Capability of Small and Medium-Sized Enterprises
}

\author{
Mohd Nizam Ab Rahman ${ }^{1, *}$, Mahmood Doroodian ${ }^{1, \dagger}$, Yusniza Kamarulzaman ${ }^{2, \dagger}$ and \\ Norhamidi Muhamad ${ }^{1, \dagger}$
}

1 Department of Mechanical and Materials Engineering, Faculty of Engineering and Built Environment, Universiti Kebangsaan Malaysia, 43600 Bangi, Selangor, Malaysia;

E-Mails: Mhdoroodian@gmail.com (M.D.); m.norhamidi@gmail.com (N.M.)

2 Department of Marketing, Faculty of Business and Accountancy, University of Malaya, Kuala Lumpur 50603, Malaysia; E-Mail: yusniza@um.edu.my

$\dagger$ These authors contributed equally to this work.

* Author to whom correspondence should be addressed; E-Mail: mnizam@eng.ukm.my; Tel.: +603-8921-6449; Fax: +603-8911-8389.

Academic Editor: Gayle C. Avery

Received: 14 October 2014 / Accepted: 23 December 2014 / Published: 6 January 2015

\begin{abstract}
The business environment is currently characterized by intensified competition at both the national and firm levels. Many studies have shown that innovation positively affect firms in enhancing their competitiveness. Innovation is a dynamic process that requires a continuous, evolving, and mastered management. Evaluating the sustainability of overall innovation capability of a business is a major means of determining how well this firm effectively and efficiently manages its innovation process. A psychometrically valid scale of evaluating the sustainability of overall innovation capability of a firm is still insufficient in the current innovation literature. Thus, this study developed a reliable and valid scale of measuring the sustainability of overall innovation capability construct. The unidimensionality, reliability, and several validity components of the developed scale were tested using the data collected from 175 small and medium-sized enterprises in Iran. A series of systematic statistical analyses were performed. Results of the reliability measures, exploratory and confirmatory factor analyses, and several components of validity tests strongly supported an eight-dimensional (8D) scale of measuring the sustainability of overall innovation capability construct. The dimensions of the scale were strategic management, supportive culture and
\end{abstract}


structure, resource allocation, communication and networking, knowledge and technology management, idea management, project development, and commercialization capabilities.

Keywords: sustainability; overall innovation capability; small and medium-sized enterprises; automobile industry; measurement model

\section{Introduction}

The rapid changes in technologies and globalization process have altered the previous rules of competition, and innovation has become increasingly essential for companies to remain competitive in the market [1,2]. Many studies have indicated that innovation can positively affect industrial firms by enhancing their competitiveness [3]. Technological innovation in the form of new or improved products and processes can be an important source of market and cost advantages for a firm; it can also increase the demand by product differentiation and enhance the ability of firms to innovate [4]. Innovation is different from generating an idea, a method of executing works or technology. Instead, innovation must be considered a sustainable and continuous process of identifying and seizing opportunities in the ever-changing business environment [2,5]. Consequently, companies must commit to sustainability of their overall innovation capability, which is the critical driver toward sustained competitive advantages [6]. In fact, the sustainability of overall innovation capability has become a reality for companies through a continuous, evolving, and mastered management of the innovation process [2]. Rejeb et al. [2] concluded that measuring the innovation activities and efforts of a firm is a crucial mechanism of ensuring a sustainable innovation capability via effective innovation management (Figure 1).

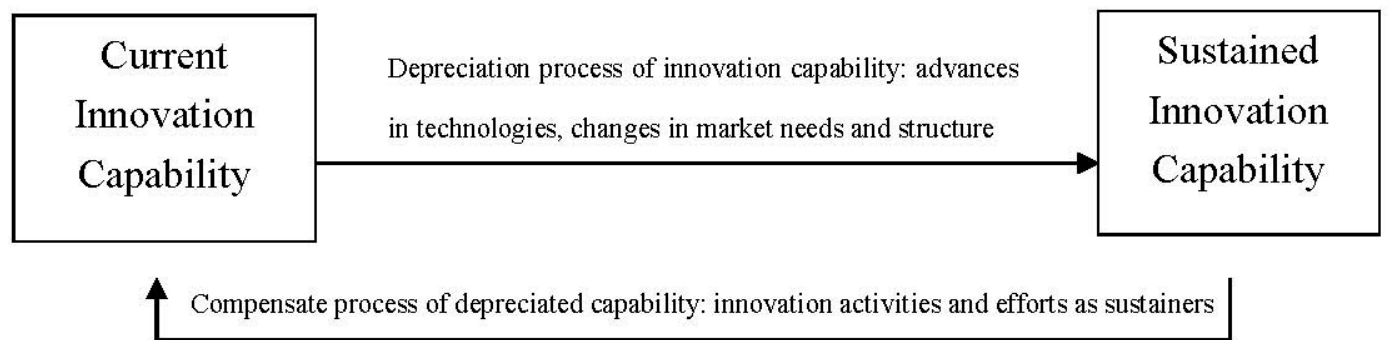

Figure 1. Innovation activities and efforts as sustainers of innovation capability.

For many companies, quantifying and assessing the process of innovation and its practices is an important and complex issue [7]. In particular, an important challenge in accomplishing such a process is measuring innovation activities, particularly the complex processes that affect the innovation capabilities of an organization to be optimally managed [8]. Measuring innovation capability is critical for both practitioners and academicians, yet the literature is characterized by diverse approaches, prescriptions, and practices that can be confusing and contradictory [9].

The literature indicates a considerable body of research in the field of innovation capability measurement $[9,10]$. The majority of studies focus on measuring the current state of innovation capabilities in terms of inputs and outputs of the innovation process, disregarding the concluding 
improvement dynamism of the process $[2,9,10]$. In this case, a strong limitation exists in terms of a dynamic capability standpoint; the activities that sustain the innovation capabilities are not evaluated. Thus, this study focuses on gauging innovation based on managerial activities and efforts instead of the outputs or inputs of the innovation process.

This study aims to develop a scale for measuring the sustainability of overall innovation capability construct based on innovation activities and to assess the psychometric properties of this scale. The remainder of the paper is organized into six sections. Following the Introduction, Section 2 briefly reviews the literature related to innovation measurement. Section 3 explains the methods employed in this study for the measurements, sampling, data collection, and analyses. Section 4 describes the results of the analyses using both descriptive and inferential methods, and Section 5 discusses the findings. Finally, Section 6 concludes the paper.

\section{Innovation Measurement}

Substantial research was conducted in the field of innovation measurement in the national and firm levels [2,11]. The majority of these studies evaluated the innovativeness of a firm based on the inputs or outputs of the innovation process to consider the process as inputs, activities, and outputs [12-16]. This approach to innovation measurement has certain drawbacks, especially in the cases of Small And Medium-Sized Enterprises (SMEs) and companies of developing countries.

The level of research and development $(R \& D)$ expenditures is repeatedly used as the overall measure of the innovativeness of firms [9,10]. However, R\&D is an input to innovation process that does not essentially lead to innovations $[17,18]$. Therefore, $R \& D$ expenditures are assumed as an over-estimated measure of innovativeness because they consider unsuccessful R\&D efforts [10]. Moreover, all new products and processes are not essentially generated in R\&D laboratories [19]. Innovations can emerge in response to a specific problem or a smart idea that the innovator unexpectedly had. In this case, evaluating innovativeness by using $R \& D$ expenditures underestimates the level of innovativeness [10]. Eventually, the R\&D data that are used as an indicator of innovation favor large firms than the SMEs because the R\&D efforts of the latter are often informal, may not be recorded [18,20], or are infrequent [19].

Patent data are one of the intermediate output measures that are frequently used as the global measure of innovativeness of firms. These data, however, gauge inventions rather than innovations [17,21,22]. Innovation refers to the process of converting an invention into a useful and marketable new or improved product or process. Measuring innovation with patent data has the risk of overestimating the level of innovativeness by counting in the measurement of the inventions that are not transformed into marketable innovations [10]. The tendency to patent innovations varies between industries [19]. For various reasons (e.g., high costs, difficulties in patenting process, relatively high imitation costs, etc.), certain companies prefer to protect their innovations by performing other appropriate methods, such as maintaining a lead time over rivals, industrial secrecy, and technological complexity [18,23,24]. All innovations are not required to be patented. Hence, patent data are an imprecise measurement of innovation [10].

The literature also indicates two sets of output-based measures of assessing the innovativeness of a firm. These sets of measures are the direct innovation count and firm-based surveys. In the first method, which can be considered an objective approach, the data on innovation are collected from various 
sources, such as new product/process announcements, databases, and specialized journals [10]. In the second measurement method, which can be regarded as a subjective approach, the surveys conducted with companies and the information on innovations is collected from firms through interviews and/or surveys [10].

However, the innovation count and firm-based surveys have some deficiencies. In practice, the innovation count favors product over process innovations [17,18,25] and radical innovations over incremental ones [22]. Moreover, this approach excludes failed innovations and avoids any comparative analysis of success and failure innovations. In this method, the researcher must assess the innovations under study. However, because the researcher is not a professional in different fields, such assessment may lead to idiosyncratic bias. Consequently, a set of experts are required to measure the innovations [23].

The major drawbacks of firm-based surveys are the representativeness of the measurement results and the fact that the answer rates are insignificant [26]. Another disadvantage of this method is related to its methodology, which measures the newness or innovativeness of a firm by asking dichotomous questions; one of which is whether firms have innovated or not. Amara et al. [27] noted that the results of this type of question indicated that the proportion of innovative firms has constantly and significantly increased for the last decade; in some countries, the proportion has increased to approximately $80 \%$. However, the research findings based on this approach of innovation measurement are becoming less and less valuable because empirical studies, instead of shedding new light on the nature of innovation process and its related factors, present further evidence, which confirms previous results [10].

In summary, this research is motivated by reviewing the above limits in the present innovation measurement approaches, which focus only on measuring the inputs and/or outputs of the innovation process. This study proposes a construct termed "Sustainability of Overall Innovation Capability" (SUSTINOVAT) and a measurement model for evaluating the construct. The SUSTINOVAT construct is regarded as a proxy of the ability of a firm to maintain or improve its innovation capabilities for future innovations against factors that depreciate such capabilities over time (e.g., advances in technologies, changes in customers' expectations or market structures, changes in competitors' competencies). Sustained innovation capability is achieved by a firm by conducting innovation activities and efforts to compensate its depreciated capabilities or even improve its overall innovation capability over time. The SUSTINOVAT's measurement model is a developed scale that measures the SUSTINOVAT construct based on evaluating the innovation activities and efforts of a firm rather than innovation inputs or outputs. This new approach of measuring innovation is consistent with the recommendation of OECD [4] for developing countries, that is, "measurement exercises should focus on the innovation process rather than its output and emphasis on how capabilities efforts and results are dealt with" (p. 139).

\section{Research Method}

Several procedures, including domain identification, item generation, data collection, scale development, and scale qualification, were completed to develop a scale of measuring the SUSTINOVAT construct [28]. 


\subsection{Specifying Domain of the Construct}

Churchill [28] elucidated that the first step in developing a scale of measuring a construct is to delineate what must be included in and/or excluded from the definition of the construct. The definition of Szeto [29], that is, "A continuous improvement of the overall capability of firms to generate innovation" was initially used to delineate the domain of the SUSTINOVAT construct. Innovations may manifest in different forms comprising product, process, organizational and marketing innovations [4]. This study focuses on product and process innovations. The degree of novelty can vary ranging from the incremental improvements in existing products and process to radical changes in the form of entirely new products and processes. This research included both improvements in the existing products and processes and the generation of entirely new ones. These four types of innovations are very close to the definition provided for technological product and process innovation in the 2nd Edition of the Oslo manual [22]. However, the manual excludes minor improvements, which are otherwise included in the domain of this study because these improvements are the dominant form of innovations in the low and medium technological industries and in the SMEs in developing countries. This remark implies that the scale developed in this study excludes organizational and marketing innovations, yet incorporates commercialization activities as a major part of product and process innovation capability. Similarly, those organizational activities (e.g., strategic management or establishment of a supportive culture) that enable industrial firms for product and process innovations are also included in the domain of this study. Based on the above discussions, the sustainability of overall innovation capability is "the ability of a firm to maintain or improve its product and process innovation capabilities over time by carrying out activities related to innovation generation, commercialization and management process successfully".

\subsection{Item Generation}

The literature review and expert survey were adopted to determine the innovation activities that may potentially sustain the overall innovation capability. A list of innovation practices was extracted. The extracted items were investigated by a multi-disciplinary consultant team, involving the academics and practitioners of innovation, SMEs, and measurement context, to examine the comprehensiveness, appropriateness, and possible overlap of the items. Consequently, some of the primary practices were eliminated, a number of new practices were suggested, and a few of them were combined.

A draft questionnaire was designed. The respondents were asked to specify the extent to which each of the practices is institutionalized in their company. A pilot test was performed in 10 industrial SMEs to improve the wording, sequence, appropriateness, and clarity of the questionnaire. Finally, 45 items were developed as measures of the SUSTINOVAT construct, known as the innovation practices (Ips).

\subsection{Sampling Design}

The subcontractor-SMEs of Iranian automaker companies were selected as the target population of this research. UNIDO [30] stated that industrial SMEs have high potential to grow in Iran. Activating this potential depends on improving the competitiveness capacity of the firms. The automobile industry is the second largest in Iran, following oil and gas. This is the only industry of Iran in which the backward linkage between large-scale companies and SMEs has formed very well [30]. 
All the active firms in this industry must have ISO-9000 and ISO-TS certification as the minimum requirement. These certificates have formed basic systems and procedures, which have facilitated information generation, documentation, and accessibility. Thus, the tendency of the respondents from the auto-industry to participate in this survey and the quality of their responses are assumed to be higher compared with those of the SMEs of other industries. A randomly-selected list of 400 industrial SMEs in the auto-industry was prepared. The agreement of managers and/or expert members of involved companies were sought at the 7th International Auto Part Exhibition (29 November to 2 December 2012) to participate in this survey in order to improve the response rate of the survey.

\subsection{Data Collection}

A survey questionnaire was developed to collect the data. The questionnaire involved three sets of questions regarding: (1) the demographic information of respondents and their firms; (2) the innovation practices; and (3) the state of innovation-related competitive performance of the firm. The respondents must be selected from individuals that are well matched to the context of this study. In particular, the potential respondents were recognized as managing directors, $R \& D$ managers, engineering managers, and well-informed experts based on the decision of firms. All the potential respondents were familiar with the topic of this study and were involved in the innovation process of their company. The questionnaire was distributed among the sample firms via email, which contained the questionnaire as a web-based link, as adopted by Forsman [31]. A reminder email was sent to those who did not respond, two weeks after the first email. A total of 181 responses were received, among which six were ignored because they were missing significant data. A total of 175 questionnaires with $43.75 \%$ response rate were used for data analysis. The non-response bias was assessed by comparing the means in the last quartile of responses and other three quartiles, as suggested by Armstrong and Overton [32]. The results of the $t$ test $(t=0.932$, sig. $=0.353)$ verified the absence of significant non-response bias in the data.

\section{Data Analysis}

\subsection{Descriptive Analysis}

Table 1 shows the summarized demographic information of the respondents and their firms. Based on their annual income, all firms had more than $75 \%$ relation to the auto-part industry and had obtained ISO-9000 and ISO-TS certificates as a prerequisite of their entry and extension of their operations in the industry.

The OECD (4) defines that small- and medium-sized firms are those with 10 to 49 and 50 to 249 employees, respectively. In total, $84 \%$ of the firms that participated in this study were medium-sized companies and the rest was small-sized. More than $85 \%$ of the respondents had 5 to 10 years of experience in the field; approximately 50\% were well-informed related experts, and 50\% were managing directors and R\&D managers. All respondents were formally educated. 
Table 1. Profile of the respondents and firms.

\begin{tabular}{|c|c|c|}
\hline Description & No. & $\%$ of Total \\
\hline \multicolumn{3}{|l|}{ Level of Education } \\
\hline BSc. & 142 & 81.14 \\
\hline Msc. & 33 & 18.86 \\
\hline \multicolumn{3}{|l|}{ Job Position } \\
\hline Managing director & 45 & 25.72 \\
\hline$R \& D$ manager & 43 & 24.57 \\
\hline Informed expert & 87 & 49.71 \\
\hline \multicolumn{3}{|c|}{ Working Experience (year) } \\
\hline$<5$ & 18 & 10.28 \\
\hline $5-10$ & 152 & 86.86 \\
\hline$>10$ & 5 & 2.86 \\
\hline \multicolumn{3}{|l|}{ Respondent's Age } \\
\hline$<40$ & 30 & 17.14 \\
\hline $40-50$ & 70 & 40.00 \\
\hline $51-60$ & 53 & 30.29 \\
\hline$>60$ & 22 & 12.57 \\
\hline \multicolumn{3}{|l|}{ Firm's Age } \\
\hline$<15$ & 26 & 14.85 \\
\hline $15-19$ & 130 & 74.29 \\
\hline$>19$ & 19 & 10.86 \\
\hline \multicolumn{3}{|l|}{ No. of Employees } \\
\hline $10-49$ & 28 & 16.00 \\
\hline $50-99$ & 37 & 21.15 \\
\hline $100-149$ & 76 & 43.43 \\
\hline $150-199$ & 24 & 13.71 \\
\hline $200-249$ & 10 & 5.71 \\
\hline
\end{tabular}

\subsection{Purifying the Generated Measures}

Item purification examines the extent to which the selected items truly belong to the domain of the SUSTINOVAT construct. Churchill [28] clarified that, if all construct items are drawn from the domain of a single construct, responses to those items must be highly inter-correlated. Conversely, low inter-item correlations indicate that some items are not extracted from an appropriate domain, thus producing errors and unreliability. Churchill [28] suggested that a simple method of improving the inter-item correlations is to eliminate the items with low item-total correlation. This is the correlation between each item and a scale score that excludes that item. If the correlation is low for an item, this means the item does not measuring the same thing as the rest of the items are measuring. The item-total correlations (an item-total correlation test is performed to check if any item in the set of tests is inconsistent with the averaged behavior of the others, and thus can be discarded) were calculated with the SPSS18. The results of the calculation revealed that these correlations were near zero for some items, which consequently must be purified. The items with a correlation near zero or the items that produced a substantial or sudden drop in the item-total correlation were removed by performing an iterative process. The process was stopped when a set of items with improved homogenous correlated item-total 
correlation were obtained. In this stage, 10 items were dropped because of their low contribution to the total correlation. Purifying these 10 items resulted in 35 items with more improved item-to-total correlations and better homogeneity across the item-total correlations of the remaining items (ranging from 0.434 to 0.683 ). The final IPs and certain selected citations are illustrated in Table A1 (Appendix).

\subsection{Exploratory Factor Analysis}

After completing the purification process, several variables were retained to measure the SUSTINOVAT construct (35 items). Accordingly, Exploratory Factor Analysis (EFA) [33] was adopted to examine the structure and dimensionality of these variables and to summarize and reduce their number. EFA primarily had an exploratory purpose because of the insufficient theoretical and empirical evidence on the dimensions and characteristics of the overall innovation capability of industrial SMEs in the literature.

The adequacy of the sampling was evaluated with the Kaiser-Mayer-Olkin (KMO) test to examine the appropriateness of the data for applying the EFA. The KMO value of 0.889 , which was greater than the recommended level of 0.50 [33], indicated that applying the EFA technique can be useful in grouping the IPs as a factor solution. The Bartlett's Test of Sphericity (approx. chi-square $=5835.602, d f=595$, sig. $=0.000)$ specified the significance of inter-item correlations. The significant inter-item correlations denoted the possibility of exploring a new factorial structure for original variables. Examining the communality of the variables revealed that all variables were suitable to be involved in the EFA process because the communality in all cases was greater than 0.5 . The principal component extraction method was used to extract the underlying factors of the variables. In particular, this method searches for the value of the total communality, which is the closest to the total observed variances [34].

The EFA was conducted with the following considerations: the eigenvalues were greater than one, the factor loadings were greater than 0.45 , and the Varimax was applied as the rotation method to identify the number of extracted factors. The results of the EFA showed that the 35 items were significantly loaded on eight different factors. This finding was confirmed by the Scree Plot (The Scree Plot is used to identify the optimum number of factors that can be extracted before the amount of unique variance begins to dominate the common variance structure.). The percentages of the explained variance of the 35 original variables were $12.353 \%, 11.623 \%, 11.426 \%, 10.002 \%, 9.864 \%, 9.413 \%, 9.015 \%$, and $8.033 \%$ by F1 to F8, respectively. The results of the test demonstrate that a total of $81.728 \%$ variance of the 35 original variables was explained by the eight extracted factors. Moreover, the minimum factor loading was 0.693, which was more than the minimum 0.50 [33]. These findings compelled the preliminarily acceptance of the eight extracted factors as the dimensions of the SUSTINOVAT construct (Table 2). Finally, based on the interpretation of the involved items in each factor and considering the factor loadings, the following names were deemed suitable for each of the eight factors as the dimensions of the SUSTINOVAT construct:

- F1: Dimension1: Knowledge and technology management capability (KTM)

- F2: Dimension2: Commercialization capability (COM)

- F3: Dimension3: Project development capability (PDV)

- F4: Dimension 4: Idea management capability (IDM)

- F5: Dimension 5: Communication and networking capability (CNT) 
- F6: Dimension6: Supportive culture and structure capability (SCL)

- F7: Dimension7: Strategic management capability (STM)

- F8: Dimension8: Resource allocation capability (RES)

Based on the results of the EFA, the SUSTINOVAT construct can be considered as the second-order latent factor that is measured by the eight dimensions (Figure 2). Each dimension is, in turn, measured as the first-order latent factor by its related observed indicators.

Table 2. The varimax rotated matrix.

\begin{tabular}{|c|c|c|c|c|c|c|c|c|}
\hline \multirow{2}{*}{ Variable } & \multicolumn{8}{|c|}{ Factor } \\
\hline & F1:KTM & F2:COM & F3:PDV & F4:IDM & F5:CNT & F6:SCL & F7:STM & F8:RES \\
\hline IP1 & 0.907 & & & & & & & \\
\hline IP2 & 0.849 & & & & & & & \\
\hline IP3 & 0.894 & & & & & & & \\
\hline IP4 & 0.871 & & & & & & & \\
\hline IP5 & 0.724 & & & & & & & \\
\hline IP6 & & 0.828 & & & & & & \\
\hline IP7 & & 0.845 & & & & & & \\
\hline IP8 & & 0.859 & & & & & & \\
\hline IP9 & & 0.803 & & & & & & \\
\hline IP10 & & 0.785 & & & & & & \\
\hline IP11 & & & 0.780 & & & & & \\
\hline IP12 & & & 0.804 & & & & & \\
\hline IP13 & & & 0.853 & & & & & \\
\hline IP14 & & & 0.856 & & & & & \\
\hline IP15 & & & 0.835 & & & & & \\
\hline IP16 & & & & 0.845 & & & & \\
\hline IP17 & & & & 0.896 & & & & \\
\hline IP18 & & & & 0.886 & & & & \\
\hline IP19 & & & & 0.859 & & & & \\
\hline IP20 & & & & & 0.876 & & & \\
\hline IP21 & & & & & 0.903 & & & \\
\hline IP22 & & & & & 0.895 & & & \\
\hline IP23 & & & & & 0.850 & & & \\
\hline IP24 & & & & & & 0.828 & & \\
\hline IP25 & & & & & & 0.865 & & \\
\hline IP26 & & & & & & 0.738 & & \\
\hline IP27 & & & & & & 0.886 & & \\
\hline IP28 & & & & & & & 0.824 & \\
\hline IP39 & & & & & & & 0.854 & \\
\hline IP30 & & & & & & & 0.830 & \\
\hline IP31 & & & & & & & 0.714 & \\
\hline IP32 & & & & & & & & 0.744 \\
\hline IP33 & & & & & & & & 0.766 \\
\hline IP34 & & & & & & & & 0.792 \\
\hline IP35 & & & & & & & & 0.693 \\
\hline$\%$ of variance & 12.353 & 11.623 & 11.426 & 10.002 & 9.864 & 9.413 & 9.015 & 8.033 \\
\hline
\end{tabular}




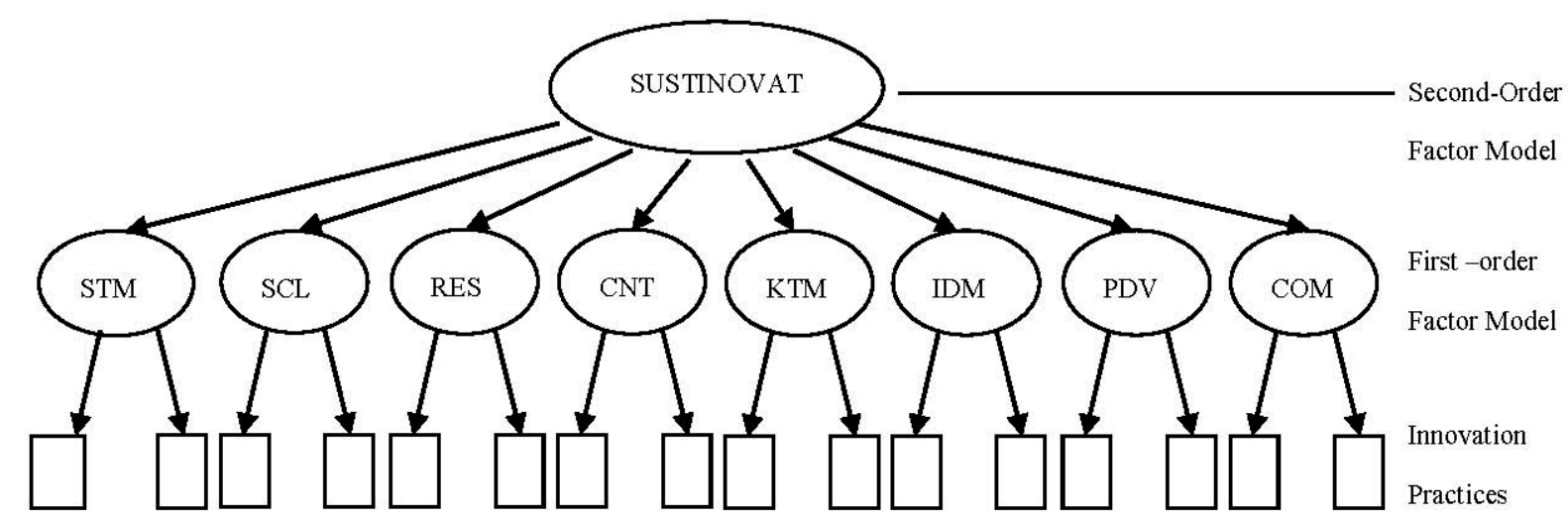

Figure 2. A second-order measurement model for evaluating the SUSTINOVAT construct.

\subsection{Confirmatory Factor Analysis}

The Confirmatory Factor Analysis (CFA) [35] was performed to assess the validity of the second-order model that was developed to gauge the SUSTINOVAT construct. The CFA involves the evaluation of an a priori measurement model, in which the observed variables are mapped onto the latent construct according to theory. This study did not acquire an a priori measurement model because of the insufficient theoretical and empirical evidence on the measures of the overall innovation capability of SMEs in the literature. Nonetheless, the CFA was conducted in this study to verify the validity of the developed model because the measures were selected on the basis of prior conceptual and empirical studies [36]. The CFA is a powerful technique to assess quality of a measurement instrument by providing quality criteria, which are not provided by the EFA (e.g., the overall model fit indices). The results of the CFA on the half of the sampled companies [33] are presented and discussed in the subsequent section.

\section{Discussion of Findings}

This research aimed to develop a model of measuring the SUSTINOVAT construct, which is deemed crucial for the further development of innovation research. The findings of this study revealed that SUSTINOVAT can be considered an 8D construct, including strategic management, supportive culture and structure, resource allocation, communication and networking, knowledge and technology management, idea management, project development, and commercialization capabilities. This study also proposed a second-order factor model of gauging the 8D model of SUSTINOVAT. This section aims to systematically evaluate the measurement properties of the second-order measurement model. Achieving such objective requires testing the model in terms of the key component of quality comprising content validity, reliability, unidimensionality and convergent validity, and discriminant and nomological validity.

\subsection{Content Validity}

An acceptable level of content validity was expected in the developed measurement scale as a result of using a logical process of scale development. The items were initially selected via an extensive related literature review, which improved the comprehensiveness and relevance of the items. Subsequently, the 
items were screened by an expert team, comprising the academics and practitioners in the context of measurement, innovation, and SME sector. The expert team examined the items in terms of appropriateness, applicability, overlap, and ambiguity. Finally, a draft questionnaire was designed, and a pilot test was performed involving 10 managers or experts of the industrial SMEs as potential respondents to improve the wording, sequence, appropriateness, and clarity of the final version of the questionnaire.

\subsection{Reliability}

Reliability is the extent to which a set of variables is consistent in what it is intended to measure [33]. The reliability of the measurement models was assessed with the measures of the coefficient alpha [37], item-total correlations [38], indicator reliability [39], and composite reliability [40]. Table 3 provides the various reliability estimates of the individual indicators and their respective latent variables (i.e., SUSTINOVAT dimensions).

Table 3. Assessment of reliability of measurement models.

\begin{tabular}{|c|c|c|c|c|c|}
\hline Dimension & Indicator & $\begin{array}{l}\text { Item-Total } \\
\text { Correlation }\end{array}$ & $\begin{array}{l}\text { Coefficient } \\
\text { Alpha }\end{array}$ & $\begin{array}{l}\text { Indicator } \\
\text { reliability }\end{array}$ & $\begin{array}{l}\text { Composite } \\
\text { Reliability }\end{array}$ \\
\hline \multirow[t]{5}{*}{ Strategic Management } & & & 0.887 & & 0.894 \\
\hline & STM1 & 0.798 & & 0.867 & \\
\hline & STM2 & 0.826 & & 0.822 & \\
\hline & STM3 & 0.806 & & 0.817 & \\
\hline & STM4 & 0.671 & & 0.394 & \\
\hline \multirow[t]{5}{*}{ Supportive Culture } & & & 0.929 & & \\
\hline & SCL1 & 0.863 & & 0.774 & \\
\hline & SCL2 & 0.791 & & 0.627 & \\
\hline & SCL3 & 0.918 & & 0.927 & \\
\hline & SCL4 & 0.770 & & 0.560 & \\
\hline \multirow[t]{5}{*}{ Resource Allocation } & & & 0.896 & & 0.896 \\
\hline & RES1 & 0.816 & & 0.793 & \\
\hline & RES2 & 0.791 & & 0.744 & \\
\hline & RES3 & 0.765 & & 0.644 & \\
\hline & RES4 & 0.720 & & 0.565 & \\
\hline \multirow[t]{5}{*}{$\begin{array}{l}\text { Communication and } \\
\text { networking }\end{array}$} & & & 0.935 & & 0.925 \\
\hline & CNT1 & 0.827 & & 0.803 & \\
\hline & CNT2 & 0.868 & & 0.822 & \\
\hline & CNT3 & 0.865 & & 0.752 & \\
\hline & CNT4 & 0.790 & & 0.642 & \\
\hline \multirow[t]{6}{*}{$\begin{array}{c}\text { Knowledge and technology } \\
\text { management }\end{array}$} & & & 0.939 & & 0.939 \\
\hline & KTM1 & 0.927 & & 0.915 & \\
\hline & KTM2 & 0.869 & & 0.855 & \\
\hline & KTM3 & 0.890 & & 0.770 & \\
\hline & KTM4 & 0.856 & & 0.705 & \\
\hline & KTM5 & 0.707 & & 0.541 & \\
\hline
\end{tabular}


Table 3. Cont.

\begin{tabular}{cccccc}
\hline Dimension & Indicator & $\begin{array}{c}\text { Item-Total } \\
\text { Correlation }\end{array}$ & $\begin{array}{c}\text { Coefficient } \\
\text { Alpha }\end{array}$ & $\begin{array}{c}\text { Indicator } \\
\text { reliability }\end{array}$ & $\begin{array}{c}\text { Composite } \\
\text { Reliability }\end{array}$ \\
\hline Idea Management & & & 0.939 & & 0.929 \\
& IDM1 & 0.829 & & 0.744 & \\
& IDM2 & 0.890 & & 0.857 & \\
& IDM3 & 0.869 & & 0.756 & \\
& IDM4 & 0.842 & & 0.735 & \\
\hline Project Development & & & 0.924 & & 0.918 \\
& PDV1 & 0.764 & & 0.618 & \\
& PDV2 & 0.782 & & 0.665 & \\
& PDV3 & 0.811 & & 0.701 & \\
& PDV4 & 0.845 & & 0.764 & \\
& PDV5 & 0.810 & & 0.698 & \\
Commercialization & & & 0.940 & 0.791 & \\
& COM1 & 0.817 & & 0.740 & \\
& COM2 & 0.873 & & 0.730 & \\
& COM3 & 0.875 & & 0.643 & \\
\hline
\end{tabular}

The coefficient alpha and composite reliability represent the internal consistency of the set of items for each dimension. Table 3 indicates that the values of the coefficient alpha range from 0.887 to 0.940 , exceeding the commonly accepted level of 0.7 [38]. The results of the assessment demonstrate that, for each SUSTINOVAT dimension, the various indicators that constitute the scale are strongly correlated with one another. Table 3 further specifies that the values of the composite reliability estimates range from 0.89 to 0.939 , exceeding the threshold level of 0.7 [41]. In other words, for each latent variable, the trait variance accounts for more than $70 \%$ of the overall measure variance.

Table 3 also exhibits the item-total correlation and indicator reliability for each of the indicators. The values of the indicator reliability range from 0.541 to 0.915 , which are all greater than the threshold level of 0.5 [41]. Similarly, all the item-total correlations are greater than 0.5 , indicating that each indicator significantly correlates with the rest of the indicators purported to measure the same latent variable [38]. Overall, the results in Table 3 provide empirical evidence for the reliability of the measures.

\subsection{Unidimensionalty and Convergent Validity}

Unidimensionality refers to the existence of a single trait, which governs a set of measures and is achieved when these measuring items contain acceptable factor loadings for the respective latent construct [33]. Meanwhile, convergent validity is the consistency in measurement across operationalizations and is achieved when all the items in a measurement model are statistically significant [33].

In this study, the unidimensionality and convergent validity of the second-order model (depicted in Figure 2) were evaluated with the CFA by assessing the overall model fit. The results of the CFA are summarized in Table 4. 
Table 4. Assessment of unidimensionality and convergent validity of the second-order model.

\begin{tabular}{cccl}
\hline Dimension & Estimates of $\boldsymbol{\beta}$ & $\boldsymbol{t}$-value & \multicolumn{1}{c}{ Fit Statistics } \\
\hline STM & 0.712 & $* *$ & $\chi^{2}(552)=798.970$ \\
SCL & 0.623 & $4.355 *$ & $p=0.000$ \\
RES & 0.848 & $5.173 *$ & $\chi^{2} / \mathrm{df}=1.447$ \\
CNT & 0.483 & $3.525 *$ & GFI (Goodness of Fit Index $)=0.683$ \\
KTM & 0.634 & $4.140 *$ & NFI (Normed Fit Index) $=0.784$ \\
IDM & 0.530 & $3.754 *$ & CFI (Comparative Fit Index) $=0.920$ \\
PDV & 0.564 & $3.967 *$ & RMSEA (Square Error of Approximation) $=0.072$ \\
COM & 0.705 & $4.541 *$ & \\
\hline
\end{tabular}

$* p<0.001 ; * *$ The $t$-value is not available, because the regression weight of the factor is fixed at 1 .

The $8 \mathrm{D}$ second-order model did not provide a good fit to the data when it was evaluated with the chi-square statistic alone. However, the evaluation results revealed that the normed $\chi^{2}\left(\chi^{2} / \mathrm{df}=1.447\right)$ is within an acceptable range $\left(\chi^{2} / \mathrm{df}<2\right)$ [35,39], also the values of CFI $(0.920)$ is greater than 0.9 , whereas the value of GFI (0.864) and NFI (0.784) fall short of the threshold level 0.9. Similarly, the value of RMSEA (0.072) is within an acceptable range (RMSEA < 0.08) [35].

Table 4 indicates that, for one of the dimensions $(\mathrm{CNT}), \beta$-value $=0.483$. This finding signifies that the CNT and SUSTINOVAT constructs have a relatively weak correlation. Nevertheless, the other $\beta$-values are greater than the threshold of 0.50 , and the entire second-order factor loadings $(\beta)$ are statistically significant with associated $t$-values at $p<0.001$. The model fit was also examined with the standardized residuals. The standardized residual matrix implies that less than $1 \%$ of cells have standardized residuals over 2.5 . No more than $10 \%$ of the absolute values of the standardized residuals must generally be greater than 2.5 [42]. Considering the above elements, all of the key statistics consistently support the unidimensionality and convergent validity of the $8 \mathrm{D}$ second-order model of measuring the SUSTINOVAT construct.

\subsection{Discriminant Validity}

Discriminant validity refers to the extent to which the measures of a latent variable (i.e., each SUSTINOVAT dimension) are unique and are thus different from the measures of other constructs. In this study, three different procedures, namely, the chi-square different, confidence intervals, and variance extracted tests, are conducted to assess the discriminant validity.

\subsubsection{Chi-square Difference Test}

With the chi-square different test $[43,44]$, the assessment of discriminant validity is achieved by completing a series of pairwise tests, comparing the unconstrained (Model 1) and constrained (Model 2) models. These pairwise tests aim to examine whether the correlation between any two dimensions is significantly different from the unity. In Model 1, the covariance between two dimensions is unconstrained, that is, the dimensions are allowed to covary. In Model 2, the covariance between two dimensions is constrained to one. Compared with Model 2, Model 1 has a significant lower chi-square statistic that supports the discriminant validity. 
Table 5 summarizes the results of the 28 pairwise comparisons of eight SUSTINOVAT dimensions. The estimates of between-dimension correlations $(\varphi)$ range from 0.007 to 0.690 , providing preliminary evidence that the dimensions are not perfectly correlated to one another. The table further indicates that the values of $\chi^{2}$ difference, each with one degree of freedom, range from 2.962 to 38.332 given that the critical value of chi-square is 10.827 at $p=0.001$. Accordingly, 26 of the 28 chi-square differences are statistically significant, that is, each of the unconstrained models provides a significant better fit than its corresponding constrained model. Consequently, the chi-square tests support discriminant validity among the dimensions.

Table 5. Chi-Square Difference Test for Assessment of Discriminant Validity.

\begin{tabular}{|c|c|c|c|c|c|c|}
\hline \multicolumn{2}{|c|}{$\begin{array}{c}\text { Dimensions } \\
\text { Compared }\end{array}$} & \multirow{2}{*}{$\frac{\chi^{2} \text { unconstrained }}{49.935(19)^{\mathrm{a}}}$} & \multirow{2}{*}{$\frac{\chi^{2} \text { constrained }}{75.444(20)^{\mathrm{a}}}$} & \multirow{2}{*}{$\frac{\chi^{2} \text { difference }}{25.509(1)^{\mathrm{a}}}$} & \multirow{2}{*}{$\begin{array}{c}\text { Estimates of } \varphi \\
0.384(0.083)^{b}\end{array}$} & \multirow{2}{*}{$\begin{array}{c}\begin{array}{c}\text { Confidence } \\
\text { Interval }\end{array} \\
{[0.218,0.550]}\end{array}$} \\
\hline STM & $\mathrm{SCL}$ & & & & & \\
\hline & RES & 26.015(19) & $47.541(20)$ & $21.526(1)$ & $0.690(0.079)$ & {$[0.532,0.848]$} \\
\hline & CNT & $25.128(19)$ & $56.013(20)$ & $30.885(1)$ & $0.294(0.080)$ & {$[0.134,0.454]$} \\
\hline & KTM & $28.336(26)$ & $50.405(27)$ & $22.069(1)$ & $0.448(0.088)$ & {$[0.272,0.624]$} \\
\hline & IDM & 21.231(19) & $58.468(20)$ & $37.237(1)$ & $0.316(0.068)$ & {$[0.180,0.452]$} \\
\hline & PDV & $49.958(26)$ & $85.362(27)$ & $35.404(1)$ & $0.392(0.066)$ & {$[0.260,0.524]$} \\
\hline & $\mathrm{COM}$ & $46.343(26)$ & $80.321(27)$ & $33.978(1)$ & $0.469(0.065)$ & {$[0.339,0.599]$} \\
\hline \multirow[t]{6}{*}{ SCL } & RES & $26.785(19)$ & $38.995(20)$ & $12.210(1)$ & $0.450(0.117)$ & {$[0.216,0.684]$} \\
\hline & CNT & $20.528(19)$ & $26.208(20)$ & $5.680(1)$ & $0.508(0.145)$ & {$[0.218,0.798]$} \\
\hline & KTM & $49.017(26)$ & $51.979(27)$ & $2.962(1)$ & $0.599(0.153)$ & {$[0.293,0.905]$} \\
\hline & IDM & 17.215(19) & $31.652(20)$ & $14.437(1)$ & $0.385(0.113)$ & {$[0.159,0.611]$} \\
\hline & PDV & $45.469(26)$ & $70.888(27)$ & $25.419(1)$ & $0.191(0.098)$ & {$[-0.005,0.387]$} \\
\hline & $\mathrm{COM}$ & $40.115(26)$ & $55.082(27)$ & $14.967(1)$ & $0.447(0.106)$ & {$[0.235,0.659]$} \\
\hline \multirow[t]{5}{*}{ RES } & CNT & 21.167(19) & $34.537(20)$ & $13.370(1)$ & $0.444(0.113)$ & {$[0.218,0.670]$} \\
\hline & KTM & $23.650(26)$ & $33.919(27)$ & $10.269(1)$ & $0.493(0.121)$ & {$[0.251,0.735]$} \\
\hline & IDM & 21.954(19) & $40.741(20)$ & $18.787(1)$ & $0.431(0.098)$ & {$[0.235,0.627]$} \\
\hline & PDV & $35.934(26)$ & $53.339(27)$ & $17.405(1)$ & $0.514(0.096)$ & {$[0.322,0.706]$} \\
\hline & $\mathrm{COM}$ & $29.193(26)$ & $46.395(27)$ & $17.202(1)$ & $0.586(0.092)$ & {$[0.402,0.770]$} \\
\hline \multirow[t]{4}{*}{ CNT } & KTM & $39.998(26)$ & $52.117(27)$ & $12.119(1)$ & $0.311(0.135)$ & {$[0.041,0.581]$} \\
\hline & IDM & $8.758(19)$ & $25.965(20)$ & $17.207(1)$ & $0.338(0.110)$ & {$[0.118,0.558]$} \\
\hline & PDV & $36.934(26)$ & $75.266(27)$ & $38.332(1)$ & $0.007(0.095)$ & {$[-0.197,0.183]$} \\
\hline & $\mathrm{COM}$ & $35.976(26)$ & $58.411(27)$ & $22.435(1)$ & $0.294(0.097)$ & {$[0.100,0.488]$} \\
\hline \multirow[t]{3}{*}{ KTM } & IDM & $30.922(26)$ & $50.997(27)$ & $20.075(1)$ & $0.249(0.111)$ & {$[0.027,0.471]$} \\
\hline & PDV & $35.528(34)$ & $51.671(35)$ & $16.143(1)$ & $0.331(0.107)$ & {$[0.117,0.545]$} \\
\hline & $\mathrm{COM}$ & $50.902(34)$ & $66.262(35)$ & $15.36(1)$ & $0.431(0.106)$ & {$[0.219,0.643]$} \\
\hline \multirow[t]{2}{*}{ IDM } & PDV & $31.938(26)$ & $52.985(27)$ & $21.047(1)$ & $0.419(0.091)$ & {$[0.237,0.601]$} \\
\hline & $\mathrm{COM}$ & $40.429(26)$ & $65.191(27)$ & $24.762(1)$ & $0.382(0.084)$ & {$[0.214,0.550]$} \\
\hline PDV & $\mathrm{COM}$ & $64.600(34)$ & $83.999(35)$ & $19.399(1)$ & $0.548(0.088)$ & {$[0.372,0.724]$} \\
\hline
\end{tabular}

${ }^{a}$ : degree of freedom in parentheses. ${ }^{b}$ : standard error in parentheses. 


\subsubsection{Confidence Interval Test}

Apart from the chi-square difference test, a confidence interval test can also be performed to assess discriminant validity [44]. This interval test involves establishing a confidence interval of two standard errors around the correlation between a pair of latent variables of interest. Evidence for the discriminant validity is provided when the interval does not include 1.0 .

Table 5 presents the correlation estimates $(\varphi)$ for the 28 pairs of dimensions and the standard error for each estimate. The confidence interval for KTM and IDM dimensions, for instance, can be calculated as $[0.249-(2 \times 0.111), 0.249+(2 \times 0.111)]=[0.027,0.471]$. Table 5 also demonstrates that the confidence intervals were computed for each pair of variables. None of the intervals includes the value of 1.0, suggesting that that the true correlation between the dimensions is not 1.0. Accordingly, the results of the confidence interval tests also support the discriminant validity.

\subsubsection{Average Variance Extracted Test}

The estimates of the average variance extracted are first computed for two dimensions of interest [45]. The estimates are then compared with the square of the correlation between the two dimensions. If both the average variance extracted estimates are greater than the squared correlation, the test provides evidence for discriminant validity.

The average variance extracted estimates for the STM, SCL, RES, CNT, KTM, IDM, PDV, and COM dimensions are $0.737,0.790,0.706,0.811,0.807,0.765,742$, and 0.748 , respectively. These estimates are depicted as on-the-diagonal elements in Table 6 . The squares of correlations $(\varphi 2)$ between the 28 dimensions are also summarized as off-diagonal elements in the table. An examination of Table 6 indicates that, in all of the 28 cases, the variance extracted estimates are greater than the square of correlation. All cases meet the requirement of the variance extracted test. Thus, the results of the examination provide evidence for discriminant validity.

Table 6. Variance extracted tests for assessment of discriminant validity.

\begin{tabular}{lcccccccc}
\hline & STM & SCL & RES & CNT & KTM & IDM & PDV & COM \\
\hline STM & $0.737^{\text {a }}$ & & & & & & & \\
SCL & $0.147^{\mathrm{b}}$ & 0.790 & & & & & & \\
RES & 0.476 & 0.203 & 0.706 & & & & & \\
CNT & 0.086 & 0.258 & 0.197 & 0.811 & & & & \\
KTM & 0.201 & 0.359 & 0.243 & 0.097 & 0.807 & & & \\
IDM & 0.100 & 0.148 & 0.186 & 0.114 & 0.062 & 0.765 & & \\
PDV & 0.154 & 0.036 & 0.264 & 0.000 & 0.110 & 0.176 & 0.742 & \\
COM & 0.220 & 0.200 & 0.343 & 0.086 & 0.186 & 0.146 & 0.300 & 0.748 \\
\hline \multicolumn{7}{c}{ a: AVE estimates on the diagonal; ${ }^{\text {b: }}$ Square of correlations on the off-diagonal. }
\end{tabular}

Based on the above analyses, the three tests performed thus far are supportive of the discriminant validity of the eight dimensions of the SUSTINOVAT construct. 


\subsection{Nomological Validity}

The nomological validity of the developed scale was analyzed by hypothesizing that the sustained innovation capability of a firm is one of the determinants of competitive performance, as noted in the literature [46-48]. The hypothesis was examined by measuring the competitive performance of a firm through the product and process competitive performances. The competitive performance of products (PRDCPER) was evaluated using three items, including the constant or increasing market share for the existing products, gaining a share of the market for new requested products, and extending the variety of customers. Meanwhile, the competitive performance of processes (PRCCPER) was assessed using five items, including the reduction of unit cost of manufacturing, improvement of the existing quality of products, flexibility in production capacity, the increasing flexibility of production process, and the reduction of time to respond to the needs of customers [49]. All items were measured by adopting five-point interval scales ranging from 1 to 5 . The respondents were asked to specify the extent to which they were competitive in the performance item in comparison to their main competitors. The score for each performance (product and process) was calculated by the summation of its item's scores. Two simple regression models were used to examine the hypothesized positive relation between the SUSTINOVAT construct as the independent variable, and the product and process performance as the dependent variables. The findings of the statistical analysis are summarized in Table 7. The table illustrates that the two regression models are both statistically significant at $p<0.001$. In both models, the coefficient $\beta$ of the SUSTINOVAT as the independent variable was positive with values of 0.462 and 0.571 and was statistically significant in the model based on the $t$ values 4.828 and 6.453 . The $\mathrm{R}^{2}$ values of the two models indicate that the variation in the independent variable accounts for $23.311 \%$ and $41.635 \%$ of the variation in the competitive performances of products and processes as dependent variables, respectively. The above-mentioned results verify the nomological validity of the developed scale.

Table 7. Assessment of nomological validity.

\begin{tabular}{ccccccc}
\hline & R & $\mathbf{R}^{\mathbf{2}}$ & F & $\boldsymbol{P}$-value & $\boldsymbol{\beta}$ & t \\
\hline PRDCPER $^{\text {a,c }}$ & 0.462 & 0.213 & 23.311 & 0.000 & 0.462 & 4.828 \\
PRCCPER $^{\text {b,c }}$ & 0.571 & 0.326 & 41.635 & 0.000 & 0.571 & 6.453 \\
\hline
\end{tabular}

${ }^{\text {a}}$ : dependent variable for Model $1{ }^{\text {b }}$ : dependent variable for Model $2{ }^{c}{ }^{c}$ : SUSTINOVAT is the independent variable for both models.

\subsection{Discussion of the Findings}

Figure 3 summarizes four major findings of this study. Firstly, the findings suggest the (8D) eight dimensions of SUSTINOVAT construct, which were extracted from the study, that are expected to sustain the overall innovation capacity of SMEs in the auto-industry in Iran. The eight-dimensional construct which comprised of strategic management, supportive culture and structure, resource allocation, communication and networking, knowledge and technology management, project development, idea management, and commercialization capabilities are the key drivers to sustain the innovation capacity among the SMEs. This findings provide a more holistic approach to measurement that recognizes all aspects of innovation capacity and sustainability. This multiplicity nature of innovation capability construct has been well recognized in the innovation literature $[5,9]$. 


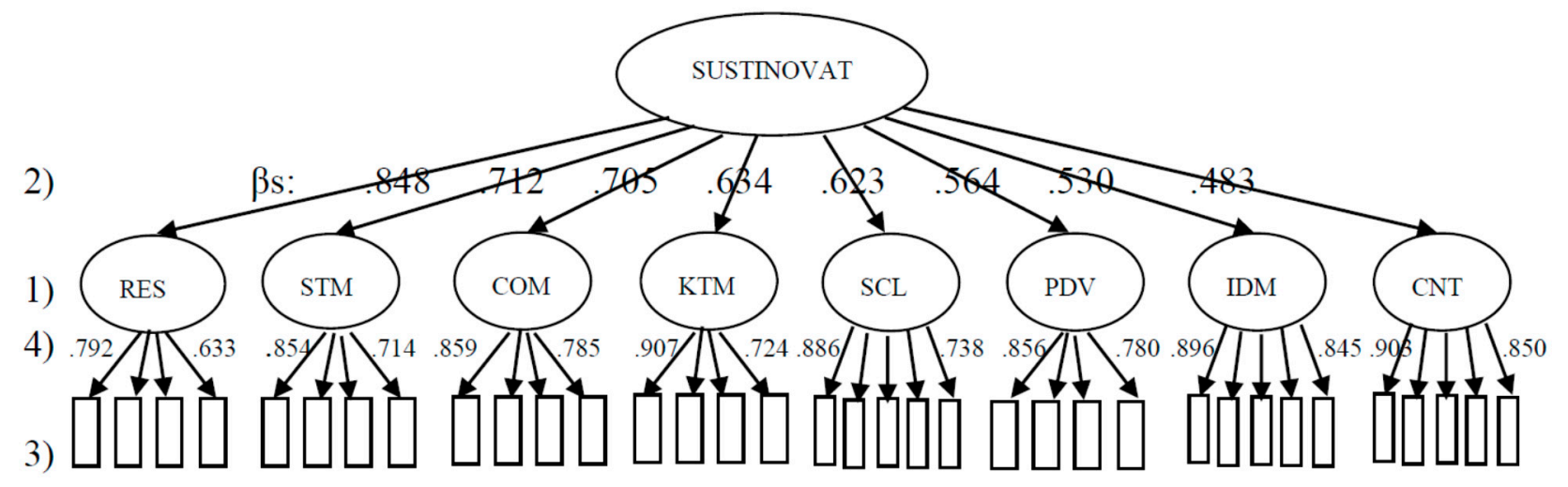

Figure 3. Summary of findings.

Secondly, the findings highlight the relative contributions of each dimension (j), to sustain the overall innovation capacity $\left(\beta_{\mathrm{j}}\right)$. Although the importance of such factors in the creation of innovation capability is available in the literature, there has been little research in the way of formal studies to examine the relative importance of such capabilities in SME sector. The findings suggest the resource allocation capability is the strongest driver of the overall innovation capacity among auto-maker SMEs in Iran ( $\beta=0.848$ ), while communication and networking capability was found to be the least important but yet significant contribution to sustain the overall innovation capacity. This finding is partially inconsistent with the part of literature in which communication and networking was identified as the most important factor for SMEs to become innovative [20,50]. One possible explanation may be due to the fact that communication and networking is in its infancy stages in Iran resulting to incomplete understanding of the actual benefits achieved through communication and networking. However, this results are consistent with Romijn and Albaladejo [13] findings where their results did not provide much support for the contention that overall intensity of external networking would be conducive to innovativeness. Moreover, other significant dimensions in sort of their contribution to sustain the overall innovation capacity after the resource allocation $(\beta=0.848)$, are strategic management $(\beta=0.712)$, commercialization $(\beta=0.705)$, knowledge and technology management $(\beta=0.634)$, supportive culture and structure $(\beta=0.623)$, project development $(\beta=0.564)$ and idea management capability $(\beta=0.530)$. Collectively, these two findings (dimensions and their relative importance) revealed that SMEs should pay special attention to continuous improvement of the important innovation capabilities if they wish to sustain their overall innovation capacity for future innovations.

Thirdly, the findings suggest related activities $\left(\mathrm{IP}_{\mathrm{ij}}\right)$ which are pertinent to improve each of the eight dimensions. The input or output-based innovation measurement models presented in the literature do offer valuable insights into the innovation capabilities, however, they do not provide detailed direction on the means to improve these abilities. From a practical standpoint, it is critical for SME managers especially in the auto industry to identify activities and efforts that are needed to improve these capabilities. The most important advantage of the activity-based measurement model developed in this research is its ability to identify innovation activities that are required to improve the identified capabilities. In addition to this, the model has suggested relative importance activities to build and improve their pertained innovation capability. In order to identify the activities required for improving innovative capabilities of the SMEs in the automotive industry in Iran, strategic focus has to be based 
on the eight bundles of distinct but interrelated activities. Table 8 shows the eight bundles of activities and their relative importance. Each bundle is expected to improve one of the innovation capabilities.

Finally, the fourth type of findings is relative contributions of each activity (i) to improve its related capability $\left(\alpha_{\mathrm{ij}}\right)$. For instance, as presented in Table 8 , the EFA result reveals that most of the SME managers in the Iranian auto industry regard four basic activities as significant for improving resource allocation; qualified human resource with high levels of education, self-esteem, diverse backgrounds and motivation to innovate (0.792); financial support and adequate funding to innovation (0.766); facilitating the use of formal systems and tools in support of innovation (0.744); and allocating facilities and physical resources to innovation (0.633). According to these results, development of qualified human resources is the most important mean to improve resource allocation capability (0.792) while the importance of physical resources is the least but significant activity for this capability in the context of auto industry.

Table 8. Summary of findings.

\begin{tabular}{|c|c|c|c|c|c|}
\hline Capability & & & Activities & & \\
\hline $\begin{array}{l}\text { Resource Allocation } \\
(\mathbf{0 . 8 4 8 )}\end{array}$ & $\begin{array}{l}\text { Human } \\
\text { resource } \\
(0.792)\end{array}$ & $\begin{array}{l}\text { Financial resource } \\
(0.766) .\end{array}$ & $\begin{array}{l}\text { Physical resource } \\
(0.744) .\end{array}$ & $\begin{array}{l}\text { Slack resource } \\
(0.633) \text {. }\end{array}$ & \\
\hline $\begin{array}{l}\text { Strategic } \\
\text { Management (0.712) }\end{array}$ & $\begin{array}{l}\text { Business } \\
\text { vision } \\
(0.854)\end{array}$ & $\begin{array}{l}\text { Innovation strategy } \\
(0.830) \text {. }\end{array}$ & $\begin{array}{l}\text { Innovation targets } \\
\text { and search areas } \\
(0.824) \text {. }\end{array}$ & $\begin{array}{l}\text { Consistency } \\
\text { between } \\
\text { innovation } \\
\text { strategy and } \\
\text { firm's activities } \\
(0.714) \text {. }\end{array}$ & \\
\hline $\begin{array}{l}\text { Commercialization } \\
(0.705)\end{array}$ & $\begin{array}{l}\text { Market } \\
\text { analysis and } \\
\text { monitoring } \\
(0.859) \text {. }\end{array}$ & $\begin{array}{l}\text { Proficiency of } \\
\text { personnel/adequacy } \\
\text { of facilities }(0.845) \text {. }\end{array}$ & $\begin{array}{l}\text { Adherence to a } \\
\text { commercialization } \\
\text { schedule and formal } \\
\text { post-launch reviews } \\
(0.828) \text {. }\end{array}$ & $\begin{array}{l}\text { Joint venturing } \\
\text { and other } \\
\text { financing } \\
\text { methods }(0.803) \text {. }\end{array}$ & $\begin{array}{l}\text { Monitoring } \\
\text { competitor } \\
(0.785) \text {. }\end{array}$ \\
\hline $\begin{array}{l}\text { Knowledge and } \\
\text { Technology } \\
\text { Management (0.634) }\end{array}$ & $\begin{array}{l}\text { Informal } \\
\text { R\&D and } \\
\text { learning } \\
\text { activities, } \\
\text { internal } \\
\text { technological } \\
\text { efforts } \\
(0.907) \text {. }\end{array}$ & $\begin{array}{l}\text { Knowledge and } \\
\text { technology } \\
\text { acquisition (0.894). }\end{array}$ & $\begin{array}{l}\text { Knowledge and } \\
\text { technology } \\
\text { assimilation, } \\
\text { adaption \& } \\
\text { transformation } \\
(0.871) \text {. }\end{array}$ & $\begin{array}{l}\text { Technology } \\
\text { trends monitoring } \\
\text { and evaluation } \\
(0.849) \text {. }\end{array}$ & $\begin{array}{l}\text { Integration } \\
\text { of internal, } \\
\text { external, } \\
\text { tacit and } \\
\text { explicit } \\
\text { knowledge } \\
(0.724) \text {. }\end{array}$ \\
\hline $\begin{array}{l}\text { Supportive Culture } \\
\text { and Structure } \\
(\mathbf{0 . 6 2 3 )}\end{array}$ & $\begin{array}{l}\text { Supportive } \\
\text { culture for } \\
\text { innovation, } \\
\text { creativity, } \\
\text { and risk } \\
\text { taking } \\
(0.886) \text {. }\end{array}$ & $\begin{array}{l}\text { Responsibility of } \\
\text { top management } \\
\text { for innovation and } \\
\text { tolerates changes } \\
\text { and failures } \\
(0.865) \text {. }\end{array}$ & $\begin{array}{l}\text { Encouraging Open } \\
\text { communication and } \\
\text { efficient } \\
\text { cross-linked } \\
\text { communication } \\
(0.828) \text {. }\end{array}$ & $\begin{array}{l}\text { Differentiated, } \\
\text { specialized, } \\
\text { integrated and } \\
\text { flexible structure } \\
(0.738) \text {. }\end{array}$ & \\
\hline
\end{tabular}


Table 8. Cont.

\begin{tabular}{|c|c|c|c|c|c|}
\hline Capability & & & Activities & & \\
\hline $\begin{array}{l}\text { Project } \\
\text { Development } \\
(0.564)\end{array}$ & $\begin{array}{l}\text { Formation of } \\
\text { cross-functional } \\
\text { project teams } \\
(0.856) .\end{array}$ & $\begin{array}{l}\text { Improvement of } \\
\text { capabilities of } \\
\text { designing, } \\
\text { engineering, } \\
\text { prototyping, and } \\
\text { testing }(0.853) \text {. }\end{array}$ & $\begin{array}{l}\text { Use of a } \\
\text { comprehensive } \\
\text { system of } \\
\text { innovation project } \\
\text { management } \\
(835) .\end{array}$ & $\begin{array}{l}\text { Adoption of } \\
\text { high-tech tools and } \\
\text { equipment }(0.804) \text {. }\end{array}$ & $\begin{array}{l}\text { Internal } \\
\text { and } \\
\text { external } \\
\text { networking } \\
\text { and } \\
\text { cooperation } \\
(0.780) \text {. }\end{array}$ \\
\hline $\begin{array}{l}\text { Idea } \\
\text { Management } \\
(\mathbf{0 . 5 3 0 )}\end{array}$ & $\begin{array}{l}\text { Use of different } \\
\text { techniques of } \\
\text { creativity and } \\
\text { idea generation } \\
(0.896) \text {. }\end{array}$ & $\begin{array}{l}\text { Acquisition of } \\
\text { innovative ideas } \\
\text { through } \\
\text { networking and } \\
\text { external relations } \\
(0.886) \text {. }\end{array}$ & $\begin{array}{l}\text { Screening of ideas } \\
\text { with the overall } \\
\text { and innovation } \\
\text { strategies of firms } \\
(0.859) \text {. }\end{array}$ & $\begin{array}{l}\text { Screening of ideas } \\
\text { by conducting } \\
\text { multi-criteria } \\
\text { feasibility study } \\
(0.845) \text {. }\end{array}$ & \\
\hline $\begin{array}{l}\text { Communication } \\
\text { and Networking } \\
(\mathbf{0 . 4 8 3 )}\end{array}$ & $\begin{array}{l}\text { Intimate } \\
\text { communication } \\
\text { with customers } \\
\text { in all stages of } \\
\text { the innovation } \\
\text { process }(0.903) \text {. }\end{array}$ & $\begin{array}{l}\text { Attendance in } \\
\text { national and } \\
\text { international } \\
\text { related } \\
\text { exhibitions } \\
(0.895) \text {. }\end{array}$ & $\begin{array}{l}\text { Membership and } \\
\text { networking with } \\
\text { industrial and } \\
\text { professional } \\
\text { associations } \\
(0.876) \text {. }\end{array}$ & $\begin{array}{l}\text { Communication } \\
\text { with competitors } \\
\text { and national and } \\
\text { international } \\
\text { industrial service } \\
\text { providers }(0.850) \text {. }\end{array}$ & \\
\hline
\end{tabular}

In summary, if SME managers of Iranian automaker companies wish to improve their innovation capabilities, they should pay special attention to these bundles of activities.

\section{Conclusions}

This study aimed to develop a scale of measuring the SUSTINOVAT construct, which is deemed important for the further development of innovation research. However, a psychometrically-valid scale of evaluating the sustainability of overall innovation capability is yet to be developed. The findings of this study suggested that an 8D measuring model, including the strategic management, supportive culture and structure, resource allocation, communication and networking, knowledge and technology management, project development, idea management, and commercialization capabilities, is reliable and valid to evaluate the sustainability of overall innovation capability. The reliability, unidimensionality, discriminant, and convergent validities of the proposed model were tested by performing a series of analyses using the data collected from 175 subcontractor SMEs in the automobile industry of Iran. The reliability measures, unidimensionality, convergent, and discriminant validity tests strongly supported the proposed scale. Moreover, the nomological validity was verified, suggesting the predictive validity of the model.

The remarkable implications of this study are as follows:

(1) For academicians, the study findings indicate that the sustainability of overall innovation capability of a firm can be measured using its innovation activities and efforts instead of its innovation inputs or outputs. This approach of measuring innovation considers the activities and efforts that have not resulted in the innovation output yet. This type of innovative activities is the dominate means of 
innovating incremental products and processes in the SMEs of developing countries; (2) For practitioners, the developed scale can facilitate in measuring and managing the innovation process as an important competitive weapon. The model presents a practical procedure of gauging the innovation capability of an organization. A key managerial aspect of this scale is its focus on the activities that a firm requires for it to become innovative. Other than firm managers, the external policy and decision makers can also use the developed scale as a comparative measure. For example, large-scale companies, as the customer of industrial SMEs (e.g., approximately 2000 subcontractors in Iran's automobile industry), can use this scale to discriminate and categorize the subcontractors for substantial decisions such as subcontractor selection for new product development or assigning market share to a certain subcontractor. Policy makers and developmental organizations may also employ the scale to determine their priorities for financial or training support.

This study has certain limitations that must be acknowledged, introducing opportunities for future research. First, the scale of measuring the overall innovation capability was developed and tested only within the industrial SMEs of automobile industry. Thus, more studies must be conducted in other industries such as electronic industry. Second, the single informant bias might be an issue in this research because only one of the general managers, R\&D managers, engineering manages, or a well-informed expert completed the questionnaire. Future research must attempt to address such concerns by asking two or more of the above-mentioned informants to complete the questionnaire. Finally, this study was conducted in the economic and industrial environment of Iran, which may be different from other developed or developing countries. Replicating this research in other countries can help check and validate the applicability of the findings of this study in other parts of the world.

The scale developed in this study advances further research opportunities in the field. One research opportunity is to examine the factors that drive or hinder the innovation capability of industrial SMEs. Kumar and Subrahmanya [51] investigated the influences of large-scale companies and the contribution of Trans National Contributions (TNCs) customers on the innovation capability of the industrial SMEs in India. The other determinants of innovation capability of the industrial SMEs must still be identified and investigated in other countries. The second research opportunity is to explore the performance of industrial SMEs resulting from their innovation capability. The suggested areas for further study can potentially expand the understanding on the field of innovation among industrial SMEs.

\section{Acknowledgments}

The authors would like to express their deepest gratitude to anonymous reviewers for their valuable feedback. Our heartfelt thanks go to all respondents who completed the questionnaires. We are also indebted to the National University of Malaysia in providing financial support from the (UKM) Grant FRGS/2/TK01/UKM02/02.

\section{Author Contributions}

Mohd Nizam Ab Rahman contributed in developing the conception of the research design; data interpretation; and writing. Mahmood Doroodian contributed in the development and execution of the research approach; literature review; data collection and interpretation; and writing. Yusniza Kamarulzaman 
and Norhamidi Muhamad contributed in enhancing the research approach; data collection and interpretation; and writing.

\section{Appendix}

Table A1. The selected citations that the measures were extracted.

\begin{tabular}{|c|c|c|}
\hline Practices & $\begin{array}{l}\text { Description } \\
\end{array}$ & Selected Citations \\
\hline IP1 & $\begin{array}{l}\text { The existence of a fully communicated business vision is } \\
\text { clearly linked to innovation. }\end{array}$ & {$[9,52]$} \\
\hline IP2 & $\begin{array}{l}\text { In a systematic manner, the innovation strategy is deployed } \\
\text { and is regularly reviewed based on the vision of firms. }\end{array}$ & {$[53]$} \\
\hline IP3 & $\begin{array}{l}\text { Coherent innovation targets and search area are designed } \\
\text { and are frequently reviewed based on the innovation } \\
\text { strategy of firm. }\end{array}$ & {$[53]$} \\
\hline IP4 & $\begin{array}{l}\text { Innovation decisions and activities are consistent with the } \\
\text { vision, innovation strategy, and targets of firms. }\end{array}$ & {$[54]$} \\
\hline IP5 & $\begin{array}{l}\text { Organization structure is appropriately differentiated, } \\
\text { specialized, and integrated and is flexible to follow the } \\
\text { innovation-focused strategy. }\end{array}$ & {$[55,56]$} \\
\hline IP6 & $\begin{array}{l}\text { Organizational culture encourages innovation, creativity, } \\
\text { and risk taking. }\end{array}$ & {$[56]$} \\
\hline IP7 & $\begin{array}{l}\text { The top management is responsible for innovation and } \\
\text { tolerates changes and failures. }\end{array}$ & {$[54]$} \\
\hline IP8 & $\begin{array}{l}\text { Open communication and efficient cross-linked } \\
\text { communication are considered facilitating, promoting, and } \\
\text { supporting mechanisms. }\end{array}$ & {$[57]$} \\
\hline IP9 & $\begin{array}{l}\text { Financial support and adequate funding for } \\
\text { innovation activities. }\end{array}$ & {$[58]$} \\
\hline IP10 & $\begin{array}{l}\text { People with high levels of education, self-esteem, diverse } \\
\text { backgrounds, motivation to innovate, and prefer to work }\end{array}$ & {$[59]$} \\
\hline IP11 & Facilities and physical resources & [9] \\
\hline IP12 & $\begin{array}{l}\text { Facilitate the use of formal systems and tools in support of } \\
\text { innovation }\end{array}$ & {$[60]$} \\
\hline IP13 & $\begin{array}{l}\text { Intimate communication and collaboration with customers } \\
\text { in all stages of the innovation process }\end{array}$ & {$[25]$} \\
\hline IP14 & $\begin{array}{l}\text { Collaboration and communication with competitors and } \\
\text { national and international industrial service providers }\end{array}$ & {$[61]$} \\
\hline IP15 & $\begin{array}{l}\text { Membership and networking with industrial and } \\
\text { professional associations }\end{array}$ & {$[62]$} \\
\hline IP16 & Attendance in national and international related exhibitions & [63] \\
\hline IP17 & $\begin{array}{l}\text { Encouragement and support of informal R\&D activities, } \\
\text { learning organization, and internal technological efforts }\end{array}$ & {$[13,51]$} \\
\hline IP18 & Acquisition of knowledge and technology & {$[61,64]$} \\
\hline IP19 & $\begin{array}{l}\text { Continuous improvement of the ability of firms to assimilate, } \\
\text { adapt, and transform the acquired knowledge and technology }\end{array}$ & {$[65,66]$} \\
\hline IP20 & Monitoring and evaluating technology trends & {$[63]$} \\
\hline IP21 & $\begin{array}{l}\text { Managing the internal, external, tacit, and explicit } \\
\text { knowledge of firms to generate innovations }\end{array}$ & {$[67]$} \\
\hline IP22 & Use of different techniques of creativity and idea generation & {$[2,68]$} \\
\hline IP23 & $\begin{array}{l}\text { Acquisition of innovative ideas through networking and } \\
\text { external relations }\end{array}$ & [9] \\
\hline
\end{tabular}


Table A1. Cont.

\begin{tabular}{clc}
\hline Practices & \multicolumn{1}{c}{ Description } & Selected Citations \\
\hline IP24 & $\begin{array}{l}\text { Screening of ideas with the overall and innovation strategies } \\
\text { of firms. }\end{array}$ & {$[54,68]$} \\
\hline IP25 & $\begin{array}{l}\text { Screening of ideas by conducting multi-criteria feasibility } \\
\text { study }\end{array}$ & {$[54,68]$} \\
\hline IP26 & Formation of cross-functional project teams & {$[69]$} \\
\hline IP27 & $\begin{array}{l}\text { Improvement of the capabilities of designing, engineering, } \\
\text { prototyping, and testing }\end{array}$ & {$[3]$} \\
\hline IP28 & $\begin{array}{l}\text { Use of a comprehensive system of innovation } \\
\text { project management }\end{array}$ & {$[70]$} \\
\hline IP29 & Adoption of high-tech tools and equipment & {$[51]$} \\
\hline IP30 & Internal and external networking and cooperation & {$[71]$} \\
\hline IP32 & $\begin{array}{l}\text { Market analysis and monitoring } \\
\text { adequacy of the facilities of organizations in the field of } \\
\text { commercialization }\end{array}$ & {$[73]$} \\
\hline IP33 & $\begin{array}{l}\text { Adherence to a commercialization schedule and to formal } \\
\text { post-launch reviews }\end{array}$ & {$[74,75]$} \\
\hline IP34 & $\begin{array}{l}\text { Employment of joint venturing and other financing methods } \\
\text { of commercializing innovations }\end{array}$ & {$[76]$} \\
\hline IP35 & Monitoring competitors & {$[77,78]$} \\
\hline
\end{tabular}

Table A2. Definitions of acronyms.

\begin{tabular}{cl}
\hline Acronym & \\
\hline SMEs & Small and Medium-sized Enterprises. \\
R\&D & Research and Development. \\
OECD & Organization for Econominnovation capabilities Co-operation and Development. \\
UNIDO & United Nations Industrial Development Organization. \\
EFA & Exploratory Factor Analysis. \\
CFA & Confirmatory Factor Analysis. \\
KMO & Kaiser-Mayer-Olkin test. \\
GFI & Goodness of Fit Index. \\
NFI & Normed Fit Index. \\
CFI & Comparative Fit Index. \\
RMSEA & Square Error of Approximation \\
AVE & Average Variance Extracted \\
TNC & Trans National Corporations \\
\hline
\end{tabular}

\section{Conflicts of Interest}

The authors declare no conflict of interest.

\section{References}

1. Pitt, M.; Goyal, S.; Sapri, M. Innovation in facilities maintenance management. Build. Serv. Eng. Res. Technol. 2006, 27, 153-164. 
2. Rejeb, H.B.; Morel-Guimarães, L.; Boly, V.; Assiélou, N.D.G. Measuring innovation best practices: Improvement of an innovation index integrating threshold and synergy effects. Technovation 2008, $28,838-854$.

3. Yam, R.C.M.; Guan, J.C.; Pun, K.F.; Tang, E.P.Y. An audit of technological innovation capabilities in Chinese firms: Some empirical findings in Beijing, China. Res. Policy 2004, 33, 1123-1140.

4. OECD. Oslo Manual: Guidance for Collecting Innovation Data, 3rd ed.; OECD Publishing: Paris, France, 2005.

5. Sun, H.; Wong, S.Y.; Zhao, Y.; Yam, R. A systematic model for assessing innovation competence of Hong Kong/China manufacturing companies: A case study. J. Eng. Technol. Manag. 2012, 29, $546-565$.

6. Cooper, J.R. A multidimensional approach to the adoption of innovation. Manag. Decis. 1998, 36, 493-502.

7. Frenkel, A.; Maital, S.; Grupp, H. Measuring dynamic technical change: A technometric approach. Int. J. Technol. Manag. 2000, 20, 429-441.

8. Cordero, R. The measurement of innovation performance in the firm: An overview. Res. Policy 1990, 19, 185-192.

9. Adams, R.; Bessant, J.; Phelps, R. Innovation management measurement: A review. Int. J. Manag. Rev. 2006, 8, 21-47.

10. Becheikh, N.; Landry, R.; Amara, N. Lessons from innovation empirical studies in the manufacturing sector: A systematic review of the literature from 1993-2003. Technovation 2006, 26, 644-664.

11. Furman, J.L.; Porter, M.E.; Stern, S. The determinants of national innovative capacity. Res. Policy 2002, 31, 899-933.

12. Marques, C.S.; Ferreira, J. SME innovative capacity, competitive advantage and performance in a traditional industrial region of Portugal. J. Technol. Manag. Innov. 2009, 4, 54-68.

13. Romijn, H.; Albaladejo, M. Determinants of innovation capability in small electronics and software firms in southeast England. Res. Policy 2002, 31, 1053-1067.

14. Tang, L.; Chi, R. The evaluation criteria on ICT enterprises innovation capability-evidence from Zhejiang province. J. Converg. Inf. Technol. 2011, 6, 69-78.

15. Kang, K.N.; Park, H. Influence of government R\&D support and inter-firm collaborations on innovation in Korean biotechnology SMEs. Technovation 2012, 32, 68-78.

16. Bull, L.; Ferguson, I. Factors influencing the success of wood product innovations in Australia and New Zealand. For. Policy Econ. 2006, 8, 742-750.

17. Flor, M.L.; Oltra, M.J. Identification of innovating firms through technological innovation indicators: An application to the Spanish ceramic tile industry. Res. Policy 2004, 33, 323-336.

18. Kleinknecht, A.; van Montfort, K.; Brouwer, E. The non-trivial choice between innovation indicators. Econ. Innov. New Technol. 2002, 11, 109-121.

19. Michie, J. The internationalisation of the innovation process. Int. J. Econ. Bus. 1998, 5, 261-277.

20. Acs, Z.; Audretsch, D. Innovation and Small Firms; MIT Press: London, UK, 1991.

21. Coombs, R.; Narandren, P.; Richards, A. A literature-based innovation output indicator. Res. Policy 1996, 25, 403-413. 
22. OECD. The Oslo Manual: Proposed Guidelines for Collecting and Interpreting Technological Innovation Data, 2nd ed.; OECD Publishing: Paris, France, 1997.

23. Archibrugi, D.; Pianta, M. Measuring technological change through patents and innovation surveys. Technovation 1996, 16, 451-468.

24. Mansfield, E. How rapidly does new industrial technology leak out? J. Ind. Econ. 1985, 34, 217-223.

25. Tether, B.S. Small and large firms: Sources of unequal innovations? Res. Policy 1998, 27, $725-745$.

26. Archibugi, D.; Sirilli, G. The direct measurement of technological innovation in business. In Survey Methodology and Measurement; National Research Council: Rome, Italy, 2000.

27. Amara, N.; Landry, R.; Becheikh, N.; Ouimet, M. What factors drive radical innovations in traditional manufacturing industries? In Proceedings of the DRUID Summer Conference, Copenhagen, Denmark, 15 January 2004.

28. Churchill, G.A. A paradigm for developing better measures of marketing constructs. J. Mark. Res. 1979, 16, 64-73.

29. Szeto, E. Innovation capacity: Working towards a mechanism for improving innovation within an inter-organizational network. TQM Mag. 2000, 12, 149-157.

30. UNIDO. Strategy Document to Enhance the Contribution of an Efficient and Effective Small and Medium Sized Enterprises Sector Toindustrial and Economic Development in the Islamic Republoc of Iran; The United Nations Industrial Development Organization: Vienna, Austria, 2003.

31. Forsman, H. Innovation capacity and innovation development in small enterprises. A comparison between the manufacturing and service sectors. Res. Policy 2011, 40, 739-750.

32. Armstrong, J.S.; Overton, T.S. Estimating non-response bias in mail surveys. J. Mark. Res. 1977, $14,396-402$.

33. Hair, J.; Black, W.; Babin, B.; Anderson, R. Multivariate Data Analysis, 7th ed.; Prentice Hall: Englewood Cliff, NJ, USA, 2010.

34. Rencher, A.C. Methods of Multivariate Analysis, 2nd ed.; JOHN WILEY\&SONS, INC.: Toronto, ON, Canada, 2002.

35. Barbara, M.B. Structural Equation Modeling with Amos: Basic Concepts, Applications, and Programming, 2nd ed.; Taylor and Francis Group, LLC: New York, NY, USA, 2010.

36. Shah, R.; Goldstein, S.M. Use of structural equation modeling in operations management research: Looking back and forward. J. Oper. Manag. 2006, 24, 148-169.

37. Cronbach, L.J. Coefficient alpha and the internal structure of tests. Psychometrika 1951, 16, 297-333.

38. Nunnally, J.C. Psychometric Theory, 2nd ed.; McGraw-Hill: New York, NY, USA, 1978.

39. Hatcher, L. A Step-by-Step Approach to Using the Sas System for Factor Analysis and Structural Equation Modeling; SAS Institute Inc.: Cary, NC, USA, 1994.

40. Werts, C.E.; Linn, R.L.; Joreskog, K.G. Intra class reliability estimates: Testing structural assumptions. Educ. Psychol. Meas. 1974, 34, 25-33.

41. Bagozzi, R.P.; Yi, Y. On the evaluation of structural equation models. J. Acad. Mark. Sci. 1988, 16, 74-94. 
42. Hu, L.; Bentler, P.M. Cutoff criteria for fit indexes in covariance structure nalysis: Coventional criteria versus new alternatives. Struct. Equ. Model. 1999, 6, 1-55.

43. Anderson, J.C. An approach for confirmatory measurement and structural equeation modeling of organizational properties. Manag. Sci. 1987, 33, 525-541.

44. Anderson, J.C.; Gerbing, D. Structural equation modeling in practice: A review and recommended two step approach. Psychol. Bull. 1988, 103, 411-423.

45. Fornell, C.; Larcker, D. Evaluating structural equation models with unobservable variables and measurement error. J. Mark. Res. 1981, 56, 39-50.

46. Saunila, M.; Ukko, J. A conceptual framework for the measurement of innovation capability and its effects. Balt. J. Manag. 2012, 7, 355-375.

47. Rohrbeck, R.; Gemünden, H.G. Corporate foresight: Its three roles in enhancing the innovation capacity of a firm. Technol. Forecast. Soc. Chang. 2011, 78, 231-243.

48. Evangelista, R.; Vezzani, A. The economic impact of technological and organizational innovations. A firm-level analysis. Res. Policy 2010, 39, 1253-1263.

49. Peng, X. Improvement and Innovation Capabilities in Manufacturing: Linking Practice Bundles to Strategic Goals and Supplier Collaboration; University of Minnesota: Minnesota, MN, USA, 2007.

50. Mancinelli, S.; Mazzanti, M. Innovation, networking and complementarity: Evidence on SME performances for a local economic system in north-eastern Italy. Ann. Reg. Sci. 2008, 43, 567-597.

51. Sudhir Kumar, R.; Bala Subrahmanya, M.H. Influence of subcontracting on innovation and economic performance of SMEs in Indian automobile industry. Technovation 2010, 30, 558-569.

52. Englund, R.L.; Graham, R.J. From experience: Linking projects to strategy. J. Prod. Innov. Manag. 1999, 16, 52-64.

53. Anthony, S.D.; Eyring, M.; Gibson, L. Mapping your innovation strategy. Harv. Bus. Rev. 2006, 84, 104-113.

54. Cormican, K.; O'Sullivan, D. Auditing best practice for effective product innovation management. Technovation 2004, 24, 819-829.

55. Slappendel, C. Perspectives on innovation in organizations. Organ. Stud. 1996, 17, 107-129.

56. McDermott, C.; Stock, G.N. Organizational culture and advanced manufacturing. J. Oper. Manag. 1999, 17, 521-533.

57. Saleh, S.D.; Wang, C.K. The management of innovation-strategy, structure, and organizational climate. IEEE Trans. Eng. Manag. Decis. 1993, 40, 14-21.

58. Atuahene-Gima, K. An exploratory analysis of the input of market orientation on new product performance: A contingency approach. J. Prod. Innov. Manag. 1995, 12, 275-293.

59. Kessler, E.H.; Chakrabarti, A.K. Innovation speed: A conceptual model of context, antecedents and outcomes. Acad. Manag. Rev. 1996, 21, 1143-1191.

60. Cooper, R.G.; Edgett, S.J.; Kleinschmidt, E.J. Benchmarking best npd practices. Res. Technol. Manag. Decis. 2004, 47, 50-59.

61. Souitaris, V. External communication determinants of innovation in the context of a newly industrialised country: A comparison of objective and perceptual results from Greece. Technovation 2001, 21, 25-34. 
62. Swan, J.; Newell, S.; Scarbrough, H.; Hislop, D. Knowledge management and innovation: Networks and networking. J. Knowl. Manag. 1999, 3, 262-275.

63. Calantone, R.J.; Cavusgil, S.T.; Zhao, Y. Learning orientation, firm innovation capability, and firm performance. Ind. Mark. Manag. 2002, 31, 515-542.

64. Uzun, A. Technological innovation activities in turkey: The case of manufacturing industry, 1995-1997. Technovation 2001, 21, 189-196.

65. Landry, R.; Amara, N.; Lamari, M. Does social capital determine innovation? To what extent? Technol. Forecast. Soc. Chang. 2002, 69, 681-701.

66. Zahra, S.A.; George, G. Absorptive capacity a review, reconceptualization, and extension. Acad. Manag. Rev. 2002, 27, 185-203.

67. Nonaka, I.; Toyama, R.; Konno, N. Seci, ba and leadership: A unifed model of dynamic knowledge creation. Long Range Plan. 2000, 33, 5-34.

68. O’Regan, N.; Ghobadian, A.; Sims, M. Fast tracking innovation in manufacturing SMEs. Technovation 2006, 26, 251-261.

69. Koc, T. Organizational determinants of innovation capacity in software companies. Comput. Ind. Eng. 2007, 53, 373-385.

70. Sánchez, A.; Lago, A.; Ferràs, X.; Ribera, J. Innovation management practices, strategic adaptation, and business results: Evidence from the electronics industry. J. Technol. Manag. Innov. 2011, 6, 14-39.

71. Cantner, U.; Conti, E.; Meder, A. Networks and innovation: The role of social assets in explaining firms' innovative capacity. Eur. Plan. Stud. 2010, 18, 1937-1956.

72. Verhaeghe, A.; Kfir, R. Managing innovation in a knowledge intensive technology organisation (kito). R\&D Manag. 2002, 32, 409-417.

73. Avlonitis, G.J.; Papastathopoulou, P.G.; Gounaris, S.P. An empirically-based typology of product innovativeness for new financial services: Success and failure scenarios. J. Prod. Innov. Manag. 2001, 18, 324-342.

74. Griffin, A.; Page, A.L. An interim report on measuring product development success and failure. J. Prod. Innov. Manag. 1993, 10, 291-308.

75. Von Zedtwitz, M. Organizational learning through post-project reviews in R\&D. R\&D Manag. 2002, 32, 255-268.

76. Schoeman, M.; Baxter, D.; Goffin, K.; Micheli, P. Commercialization partnerships as an enabler of UK public sector innovation: The perfect match? Public Money Manag. 2012, 32, 425-432.

77. François, J.P.; Favre, F.; Negassi, S. Competence and organization: Two drivers of innovation. A micro-econometric study. Econ. Innov. New Technol. 2002, 11, 249-270.

78. Lukas, B.A.; Ferrell, O.C. The effect of market orientation on product innovation. Acad. Mark. Sci. J. 2000, 28, 239-247.

(C) 2015 by the authors; licensee MDPI, Basel, Switzerland. This article is an open access article distributed under the terms and conditions of the Creative Commons Attribution license (http://creativecommons.org/licenses/by/4.0/). 